\title{
PENGARUH PENGHINDARAN PAJAK TERHADAP BIAYA HUTANG PASCA PERUBAHAN TARIF PAJAK BADAN PADA PERUSAHAAN MANUFAKTUR YANG TERDAFTAR DI BURSA EFEK INDONESIA
}

\begin{abstract}
The aim of the research is to analyze tax avoidance behavior to cost of debt moderated by tax rates changes, on manufacturing company in Indonesia in 2008-2010. Panel data analysis is used in this research. In this study using book tax gap to measure tax avoidance and using the models used by Lim (2010), Dwi Martani (2011) and Widya Sartika (2012) to meansure cost of debt. The study find that tax avoidance has negative influence on cost of debt. Tax avoidance creates a risk thereby increasing the cost of debt. In the period before tax rate reduction the influence of tax avoidance on cost of debt smaller compare after period of tax reduction, this indicates the presence of earning management conducted by the company before tax rate reduction.
\end{abstract}

Keywords : Tax Avoidance, Cost of debt, and Tax Rates Change

\section{PENDAHULUAN}

Di berbagai negara pajak merupakan sebuah penerimaan yang cukup besar begitu juga di negara Indonesia. Pajak merupakan salah satu unsur terbesar dalam penerimaan pemerintah Indoonesia. Karena itulah pelaksanaan perpajakan sangat diatur oleh pemerintah Indonesia guna mempertahankan penerimaan negara. Pengertian pajak sendiri diatur dalam Undang-Undang Republik Indonesia Nomor 28 Tahun 2007 Pasal 1, yaitu kontribusi wajib kepada negara yang terhutang oleh orang pribadi atau badan yang bersifat memaksa berdasarkan Undang-Undang, dengan tidak mendapatkan imbalan secara langsung dan digunakan untuk keperluan negara bagi sebesar-besarnya kemakmuran rakyat.

Salah satu upaya pemerintah untuk meningkatkan penerimaan pajak adalah dengan selalu berupaya untuk melakukan perbaikan dan penyempurnaan atas peraturan-peraturan perpajakan di Indonesia. Perubahanperubahan peraturan perpajakan yang dilakukan oleh pemerintah untuk memperbaiki sistem perpajakan dan meningkatkan jumlah penerimaan negara di bagian pajak ini disebut reformasi pajak. Reformasi pajak juga dilakukan dengan tujuan untuk meningkatkan kesadaran warga negara untuk berpartisipasi dalam proses pembangunan melalui pembayaran pajak. Akan tetapi, banyak warga negara yang masih menganggap pajak sebagai suatu beban. Perusahaan atau badan juga masih menganggap pajak sebagai beban yang akan mengurangi laba bersih perusahaan. Wajib pajak akan cenderung mencari cara untuk memperkecil pajak yang mereka bayar, baik itu legal maupun ilegal. Dari sisi perusahaan, tujuan perusahaan memperkecil pajak adalah untuk untuk mencapai tingkat laba dan likuiditas yang ditargetkan perusahaan.

Perusahaan melakukan manajemen pajak untuk meminimumkan jumlah pajak yang harus mereka bayar. Menurut Lumbantoruan (1996) dalam Suandy (2003), manajemen pajak adalah sarana memenuhi kewajiban perpajakan dengan benar tetapi jumlah pajak yang dibayar dapat ditekan serendah mungkin untuk 
memperoleh laba dan likuiditas yang diharapkan. Salah satu bentuk manajemen pajak yang dapat dilakukan perusahaan adalah perencanaan pajak (tax planning). Dengan adanya perubahan peraturan yang mengatur tentang pajak penghasilan, yang sebelumnya diatur dalam Undang-undang No.17 tahun 2000 (berlaku sampai dengan 31 Desember 2008) dengan tariff pajak Lapisan Penghasilan s.d Rp 50.000.000,- sebesar 10\%, di atas Rp 50.000.000,- s.d. Rp 100.000.000,- sebesar 15\% , di atas Rp 100.000.000,- sebesar 30\% , menjadi Undangundang No.36 tahun 2008, terdapat penurunan tarif pajak. Penghasilan kena pajak wajib pajak Badan Dalam Negeri dan Bentuk Usaha Tetap dikenakan tarif sebesar 28\% mulai tanggal 1 Januari 2009, Tarif pajak tersebut diturunkan menjadi 25\% mulai 1 Januari 2010. Selain itu berdasarkan Pasal 31 E UU No. 36 Tahun 2008 terdapat Fasilitas Pengurangan Tarif untuk Wajib Pajak badan dalam negeri dengan peredaran bruto sampai dengan Rp 50.000.000.000,00 (lima puluh miliar rupiah) mendapat fasilitas berupa pengurangan tarif sebesar 50\% (lima puluh persen) dari tarif sebagaimana dimaksud dalam Pasal 17 ayat (1) huruf b dan ayat (2a) yang dikenakan atas Penghasilan Kena Pajak dari bagian peredaran bruto sampai dengan Rp 4.800.000.000,00 (empat miliar delapan ratus juta rupiah). Maka perusahaan yang memiliki tingkat laba yang tinggi akan merasa diuntungkan karena pajak yang harus dibayar menjadi lebih kecil sehingga perusahaan dapat mengurangi jumlah hutang yang dilakukan dalam rangka manajemen pajak tadi.

Sementara bagi perusahaan dengan tingkat laba yang rendah tidak mendapat keuntungan karena pajak yang harus dibayar menjadi lebih besar. Dan salah satu cara mengurangi jumlah pajak yang harus dibayar adalah memanfaatkan biaya bunga dengan menambah jumlah hutang mereka. Namun, apabila perusahaan memiliki terlalu banyak hutang agar biaya bunganya dapat mengurangi taxable income, maka menurut teori trade-off jumlah hutang yang besar tersebut akan meningkatkan biaya kebangkrutan (bankruptcy cost). Oleh karena itu, manajemen keuangan harus hati-hati dalam mempertimbangkan keputusan struktur modalnya. Perusahaan dituntut untuk mempertimbangkan dan menganalisis sumber-sumber dana yang ekonomis guna membiayai kegiatan usahanya. Untuk itu perusahaan perlu mempertimbangkan berbagai variabel yang mempengaruhi pengambilan keputusan struktur modal. Penelitian mengenai penghindaran pajak dan biaya hutang yang dilakukan oleh Indah Masri dan Dwi Martani (2008) menemukan bahwa pengaruh penghindaran pajak dan biaya hutang adalah signifikan positif dan pengaruh moderasi atas perubahan tarif pajak dengan penghindaran pajak negatif signifikan.

\section{KAJIAN PUSTAKA DAN PENGEMBANGAN HIPOTESIS}

\section{Penghindaran Pajak (Tax Avoidance) dan Biaya Hutang (Cost of Debt)}

Graham dan Tucker (2006) dalam Lim (2010) menyatakan bahwa penghindaran pajak adalah pengganti untuk penggunaan hutang karena hal ini dapat meningkatkan financial slack, mengurangi biaya kebangkrutan yang diharapkan, meningkatkan kualitas kredit, risiko default rendah, sehingga mengurangi biaya hutang. Menurut penelitian Graham dan Tucker (2006) perusahaan menggunakan hutang yang lebih sedikit ketika mereka terlibat dalam penghindaran pajak. Graham dan Tucker (2006) menyatakan bahwa sifat subtitusi ini juga dipengaruhi oleh penentuan stuktur modal dari perusahaan, apakah perusahaan melakukan pendanaan berasal dari modal sendiri yaitu dari modal saham dan laba ditahan atau dari pihak eksternal yaitu hutang.

Jurnal Akuntansi Indonesia 
Selain itu menurut Suandy (2003) dalam Widya Sartika (2012), manajemen pajak adalah sarana memenuhi kewajiban perpajakan dengan benar tetapi jumlah pajak yang dibayar akan ditekan serendah mungkin untuk memperoleh laba dan likuiditas yang diharapkan. Berdasarkan penjelasan tersebut, penelitian ini mengambil hipotesis bahwa penghindaran pajak berhubungan negatif dengan biaya hutang.

\section{H1 : Penghindaran pajak (tax avoidance) berhubungan negatif terhadap biaya hutang (cost of debt)}

\section{Pengaruh Moderasi Tarif Pajak Terhadap Hubungan Penghindaran Pajak (Tax Avoidance) dan Biaya Hutang (Cost of Debt)}

Upaya dalam melakukan penghematan pajak secara legal dapat dilakukan melalui perencanan pajak. Dalam praktek bisnis umunya pengusaha mengidentikkan pembayaran pajak sebagai beban, sehingga akan berusaha meminimalkan beban untuk mengoptimalkan laba. Dalam rangka meningkatkan efesiensi dan daya saing maka manager wajib menekan biaya seoptimal mungkin, demikian pula dengan kewajiban membayar pajak. Biaya dan laba berbanding terbalik, semakin tinggi biaya maka laba yang diperoleh akan semakin rendah demikian sebaliknya semakin rendah biaya yang dikeluarkan secara efesien maka laba yang diperoleh juga semakin tinggi. Dalam kurun waktu terakhir telah banyak dilakukan penelitian tentang pengaruh tax avoidance terhadap biaya hutang, baik yang dilakukan sebelum berlakunya perubahan tarif pajak penghasilan badan maupun setelah diberlakukannya penurunan tarif pajak penghasilan badan. Penelitian tersebut diantaranya : (1) Indah Masri \& Dwi Martani, 2008 dengan hasil penelitian empirisnya menunjukkan pengaruh penghindaran pajak terhadap biaya hutang atas kedua proksi pengukuran penghindaran pajak adalah signifikan positif dan Pengaruh moderasi atas perubahan tarif pajak dengan penghindaran pajak negatif signifikan (2) Widya Sartika, 2012 dengan hasil penelitian Nilai probabilitas yang dihasilkan mengindikasikan bahwa adanya korelasi negatif antara penghindaran pajak dan biaya hutang. Berdasarkan perbandingan tersebut, hipotesis dalam penelitian ini adalah

\section{H2 : Pada periode sebelum penurunan tariff pajak pengaruh penghindaran pajak terhadap biaya hutang akan lebih kuat.}

\section{METODE PENELITIAN}

\section{Populasi dan Sampel Penelitian}

Populasi dalam penelitian ini adalah perusaahaan manufaktur yang terdaftar di BEl selama tahun 20082010 yaitu sebanyak 140 perusahaan. Dari populaso tersebut sampel ditentukan, yaitu perusahaan yang memenuhi kriteria sebagai berikut : (1) Perusahaan yang laporan keuangannya tidak diukur menggunakan satuan rupiah; (2) Perusahaan dengan data tidak lengkap; (3) Perusahaan yang memiliki pendapatan negatif. Berdasarkan kriteria tersebut diperoleh sampel penelitian sebanyak 40 perusahaan.

\section{Definisi dan Operasionalisasi Variabel Penelitian}

\section{Biaya Hutang (Cost of Debt)}

Cost of debt adalah tingkat pengembalian yang diinginkan kreditur saat memberikan pendanaan kepada perusahaan (Madiasmo 2000:9). Pengukuran yang digunakan dalam variabel Biaya hutang (Cost of debt), 
(Pittman dan Fortin, 2004) adalah :

Cost Of Debt = beban bunga / Rata-rata hutang jangka pendek dan jangka pajang

Bhorajand Sengupta (2003) menunjukkan bahwa biaya hutang sebuah perusahaan ditentukankarakteristik perusahaan tersebut, dapat dilihat dari penerbitan obligasi yang mempengaruhi resiko kebangkrutan, agency cost dan masalah informasi asimetri. Biaya hutang sebagai salah satu unsur penting dalam struktur modal dipengaruhi oleh faktor pajak yaitu debt tax shields dimana beban bunga dapat dijadikan sebagai sebagai pengurang pajak terutang

\section{Penghindaran Pajak (Tax Avoidance)}

Tax avoidance adalah penghematan pajak yang timbul dengan memanfaatkan ketentuan perpajakan yang dilakukan secara legal untuk meminimalkan kewajiban pajak (James dan Prest yang diterjemahkan oleh Zain, 2003). Pengukuran tax avoidance yang digunakan dalam penelitian ini berdasarkan pengukuran Lim (2011) dan Desai dan Dharmapala (2006) sebagai robustness test untuk memperkuat hasil penelitian. Kualitas laba dapat diukur melalui dengan Discretionary Accruals (DACC). Dalam menghitung DACC, digunakan Modified Jones Model karena model ini dianggap lebih baik diantara model lain untuk mengukur manajemen laba (Dechow et al, 1995). Model perhitungannya sebagai berikut:

$$
\begin{gathered}
\text { TACCit }=\text { EBXTit }- \text { OCFit } \\
\text { TACCit/TAi,t-1 }=a 1(1 / \text { TAi,t-1 })+a 2((\Delta \text { REVit }-\triangle \text { RECit }) / T A i, t-1)+a 3(\text { PPEit/TAi,t-1 })
\end{gathered}
$$

Dari persamaan regresi diatas, NDACC dapat dihitung dengan memasukkan kembali koefisien-koefisien:

$$
\text { NDACCit }=a 1(1 / \text { TAi,t-1) }+a 2((\triangle \text { REVit }-\triangle \text { RECit }) / T A i, t-1)+a 3(\text { PPEit/TAi,t-1 })
$$

$$
\text { DACCit }=(\text { TACCit/TAi,t-1) }- \text { NDACCit }
$$

Dimana :

TACCit :Total accruals perusahaan i pada periode $t$

EBXTit : Earnings Before Extraordinary Item (Laba Bersih) perusahaan i pada periode $\mathrm{t}$

OCFit : Operating Cash Flows (Arus Kas Operasi) perusahaan i pada periode t

TAi,t-1 : :Total aktiva perusahaan i pada periode $\mathrm{t}-1$

REVit : Perubahan Revenue perusahaan i pada periode $t$

RECit : Perubahan Receivable perusahaan i pada periode $t$

PPEit : Nilai aktiva tetap (gross) perusahaan i pada periode $\mathrm{t}$

\section{Perubahan Tarif Pajak}

Perubahan tarif pajak dapat mempengaruhi perilaku dari tax avoidance. Berdasarkan UU Pajak Penghasilan No.36 tahun 2008 pasal 17 ayat (1b), penghasilan kena pajak wajib pajak Badan Dalam Negeri dan Bentuk Usaha Tetap dikenakan tarif sebesar 28\% mulai 1 Januari 2009. Selanjutnya pasal 17 ayat 2a tarif tersebut turun menjadi $25 \%$ dan berlaku 1 Januari 2010. Pengukuran perubahan tarif pajak yang digunakan dalam penelitian ini didasarkan atas uji sensitivitas yang dilakukan oleh Lim (2011).Pengukuran yang dilakukan Lim (2011) ini dapat diterapkan di Indonesia yang juga mengalami beberapa kali penurunan tarif pajak. Dalam pengukuran 
membagi tahap-tahap perubahan tarif pajak menjadi beberapa penilaian yaitu: 2 untuk tahun 2008 dengan tarif pajak 30\%,1 untuk tahun 2009 dengan tarif pajak 28\%, dan 0 untuk tahun 2010 dengan tarif pajak 25\%. Pengukuran variabel dummy ini lebih melihat kepada periode sebelum penurunan tarif pajak.

\section{Variabel Pengendali}

\section{Umur Perusahaan}

Umur perusahaan merupakan ukuran seberapa lama perusahaan tersebut melakukan penjualan saham di Bursa Efek Indonesia (Lim, 2010). Age = Tahun Sampel - Tahun Melakukan IPO

\section{Ukuran Perusahaan}

Pengukuran perusahaan dapat dilakukan dengan menggunakan total assets, total penjualan atau kapitalisasi pasar. Dari berbagai perhitungan tersebut yang paling stabil adalah dengan total assets (Manurung, 2010). Size $=\log ($ Total assets)

\section{Leverage}

Leverage merupakan rasio perhitungan yang digunakan untuk melihat nilai assets yang didanai melalui hutang dan melihat nilai aktiva yang digunakan untuk menjamin hutang perusahaan, sehingga dapat dilakukan analisa terhadap kemampuan perusahaan dalam memenuhi kewajibannya ( Manurung, 2010 ). Leverage $=$ Total Debt $/$ Total Assets

\section{Kualitas Auditor}

Pengukuran kualitas auditor dilihat berdasarkan apakah auditor berasal dari KAP Big Four atau KAP non-Big Four, karena KAP Big Four dinilai lebih kredibel dibandingkan KAP non-Big Four. Variabel ini diukur menggunakan variabel dummy angka satu untuk auditor yang berkualitas tinggi (KAP Big Four), dan angka nol untuk auditor yang berasal dari KAP non-Big Four ( Lugianto, 2008 )

\section{CFO}

Aliran kas operational merupakan aliran kas masuk (cash in flow) dan aliran kas keluar (cash out flow), apabila timgkat profitabilitas perusahaan rendah perusahaan menggunakan hutangnya untuk biaya operasional (Ismiyanti dan Hanafi, 2003 dalam Indahningrum dan Handayani, 2009). CFO = Cash Flow Operation / Total assets

\section{PPE}

PPE menggambarkan seberapa banyak jaminan yang dapat diberikan oleh perusahaan ketika mereka terlibat hutang. Jaminan berhubungan positif dengan rasio hutang (Widjaja, 2010). PPE = log ( PPE ) 


\section{Metode Pengumpulan Data}

Data-data yang digunakan dalam penelitian ini merupakan data kuantitatif yang diperoleh dari BEI berupa laporan keuangan dan laporan tahunan perusahaan manufaktur yang tersedia.

\section{Rancangan Model Analisis}

Untuk menjawab hipotesis penelitian maka teknik analisis yang digunakan adalah regresi linear berganda dengan persamaan sebagai berikut :

$$
\mathrm{Y}=\mathrm{a}+\mathrm{b}_{1} \mathrm{X} 1+\mathrm{b}_{2} \mathrm{X} 2+\mathrm{b}_{3} \mathrm{~K} 1-\mathrm{b}_{4} \mathrm{~K} 2+\mathrm{b}_{5} \mathrm{~K} 3+\mathrm{b}_{6} \mathrm{~K} 4+\mathrm{b}_{7} \mathrm{~K} 5+\mathrm{b}_{8} \mathrm{~K} 6+\mathrm{b}_{9} \mathrm{X} 1 * \mathrm{X} 2+\mathrm{e}
$$

Dimana :

$\begin{array}{llll}\mathrm{Y} & \text { : Biaya Hutang } & \mathrm{K}_{1} & \text { : Umur } \\ \mathrm{a} & \text { : Konstanta } & \mathrm{K}_{2} & : \text { Ukuran } \\ \mathrm{b}_{1}-\mathrm{b}_{9} & \text { : Koefisien Regresi } & \mathrm{K}_{3} & : \text { Leverage } \\ \mathrm{X}_{1} & \text { : Penghindaran pajak } & \mathrm{K}_{4} & : \text { Kualitas Auditor } \\ \mathrm{X}_{2} & \text { : Perubahan Tarif Pajak } & \mathrm{K}_{5} & : \text { CFO } \\ \mathrm{e} & : \text { Standart Erorr } & \mathrm{K}_{6} & : \text { PPE }\end{array}$

Hipotesis akan diterima apabila tingkat signifikasi yang dimiliki masing-masing variabel independen kurang dari 0,05.

\section{Deskripsi Objek Penelitian}

\section{HASIL PENELITIAN DAN PEMBAHASAN}

Teknik pengambilan sampel yang digunakan adalah purposive sampling disertai dengan kriteria yang ditetapkan. Berdasarkan teknik pengambilan sampel ini, maka diperoleh 40 perusahaan yang menjadi sampel. Kriteria yang digunakan dalam pengambilan sampel dapat dilihat dalam tabel 1.

\section{Analisis Statistik Deskriptif}

Berdasarkan hasil deskriptif variabel diketahui jumlah observasi yang digunakan adalah 120 observasi, dimana pada variabel penghindaran pajak yang diukur dengan DA, diperoleh nilai rata-rata sebesar -0,9345 dengan standar deviasi sebesar 1,55. Nilai variabel penghindaran pajak berkisar antara -15,89 sampai dengan 1,97. Variabel biaya hutang diperoleh nilai rata-rata sebesar 0,0364 dengan standar deviasi sebesar 1,006. Nilai variabel biaya hutang berkisar antara 0,0 sampai dengan 1,07. Variabel umur perusahaan diketahui rata-rata sebesar 17,5 dengan standar deviasi sebesar 5,89. Nilai umur perusahaan berkisar antara 2 sampai dengan 33 tahun. Variabel ukuran perusahaan yang diukur dengan total aset memiliki rata-rata sebesar 23,42 dengan standar deviasi sebesar 5,07. Nilai ukuran perusahaan berkisar antara 11,30 sampai dengan 29,58. Variabel leverage memiliki rata-rata sebesar 0,402 dengan standar deviasi sebesar 0,201. Nilai leverage berkisar antara 0,0 sampai dengan 1,08. Variabel arus kas operasi (CFO) memiliki rata-rata sebesar 0,1478 dengan standar deviasi sebesar 0,1818. Nilai arus kas operasi (CFO) berkisar antara 0,0 sampai dengan 1,74. Variabel PPE memiliki rata-rata sebesar 21,4 dengan standar deviasi sebesar 5,199. Nilai PPE berkisar antara 7,97 sampai 
dengan 28,60. Hasil uji deskriptif variabel dapat dilihat dalam tabel 2.

\section{Uji Asumsi Klasik}

Hasil pengujian normalitas residual menunjukkan diperoleh nilai probabilitas uji Kolmogorov Smirnov adalah sebesar 0,497 (>0,05). Hasil tersebut menunjukkan bahwa model regresi memiliki nilai residual yang terdistribusi normal (dapat dilihat dalam gambar 2 dan tabel 3, 4). Pengujian multikolineritas dilakukan dengan Variance Inflation Factor (VIF) juga menunjukkan hal yang sama, tidak ada satu variabel independen yang memiliki nilai VIF lebih dari 10 (dapat dilihat dalam tabel 5). Uji Heterokedastisitas menunjukkan terjadinya pola yang tidak jelas pada persebaran data, serta titik-titik menyebar diatas dan dibawah angka 0 pada sumbu Y, maka dapat disimpulkan tidak terjadi heteroskedastisitas (dapat dilihat pada gambar 3). Pengujian Autokorelasi dapat dilakukan dengan menggunakan runt test, menunjukkan bahwa diperoleh nilai test adalah $-0,00349$ dengan probabilitas 0,267 . Oleh karena probabilitas lebih besar 0,05 , maka menunjukkan nilai residual acak atau random, sehingga dapat disimpulkan tidak terjadi autokorelasi antar nilai residual (dapat dilihat pada tabel 6 dan 7). Dari pengukuran penghindaran pajak diketahui bahwa koefisien determinasi nilai Adjusted R square sebesar 0,111. Nilai ini menerangkan besarnya peran atau kontribusi variabel bebas dan variabel kontrol, yakni penghindaran pajak, biaya hutang, perubahan tarif pajak, umur, ukuran perusahaan, leverage, kualitas auditor, CFO dan PPE serta variabel moderat mampu menjelaskan variabel biaya hutang sebesar 11,1\%, sedangkan sisanya 88,9\% dijelaskan oleh variabel lain diluar model (hasil Uji Koefisiensi Determinasi $\left({ }^{2}\right)$ dapat dilihat tabel 8). Sedangkan dari hasil uji statistik F diperoleh diperoleh nilai F-hitung sebesar 2,620 dengan signifikansi 0,009. Oleh karena signifikansi lebih kecil dari 0,05, maka dapat dikatakan bahwa penghindaran pajak, biaya hutang, perubahan tarif pajak, umur, ukuran perusahaan, leverage, kualitas auditor, CFO dan PPE secara bersama-sama atau simultan mempengaruhi variabel biaya hutang (hasil uji $F$ dapat dilihat pada tabel 9).

\section{Pengujian Hipotesis dan Pembahasan Penghindaran Pajak dan Biaya Hutang}

Berdasarkan analisis perhitungan regresi linier berganda yang telah dilakukan penghindaran pajak memiliki nilai koefisien regresi sebesar -0,02. Hal ini menjelaskan jika penghindaran pajak naik satu satuan, akan berakibat pada turunnya biaya hutang sebesar 0,02\% namun dengan asumsi variabel lain konstan. Variabel perubahan tariff pajak memiliki nilai koefisien regresi sebesar 0,002. Hal ini menyatakan setiap kenaikan perubahan tariff pajak satu persen akan meningkatkan biaya hutang sebesar $0,002 \%$, namun dengan asumsi variabel lain konstan. Variabel umur memiliki nilai koefisien regresi sebesar 0,000. Hal ini menyatakan bahwa setiap setiap kenaikan umur satu persen akan berakibat naiknya biaya hutang $0,000 \%$, namun dengan asumsi variabel lain konstan. Variabel Ukuran Perusahaan memiliki nilai koefisien regresi sebesar -0,002. Hal ini menyatakan bahwa setiap setiap kenaikan ukuran perusahaan satu persen akan berakibat turunnya biaya hutang 0,002\%, namun dengan asumsi variabel lain konstan. Variabel Leverage memiliki nilai koefisien regresi sebesar 0,043 . Hal ini menyatakan bahwa setiap setiap kenaikan leverage satu persen akan berakibat naiknya 
biaya hutang 0,043\%, namun dengan asumsi variabel lain konstan. Variabel Kualitas Auditor memiliki nilai koefisien regresi sebesar -0,002. Hal ini menyatakan bahwa setiap setiap kenaikan kualitaas auditor satu persen akan berakibat turunnya biaya hutang 0,002\%, namun dengan asumsi variabel lain konstan. Variabel CFO memiliki nilai koefisien regresi sebesar -0,056. Hal ini menyatakan bahwa setiap setiap kenaikan CFO satu persen akan berakibat turunnya biaya hutang 0,056\%, namun dengan asumsi variabel lain konstan. Variabel PPE memiliki nilai koefisien regresi sebesar 0,002. Hal ini menyatakan bahwa setiap setiap kenaikan ukuran perusahaan satu persen akan berakibat naiknya biaya hutang 0,002\%, namun dengan asumsi variabel lain konstan.

Sedangkan berdasarkan output yang dihasilkan dapat disimpulkan bahwa dari hasil uji t diperoleh nilai t hitung sebesar $-0,738$ dan tingkat signifikansi sebesar 0,462 $(>0,05)$. Hasil ini menunjukkan bahwa penghindaran pajak tidak berpengaruh signifikan terhadap biaya hutang, sehingga hipotesis pertama dalam penelitian ini ditolak. Nilai koefisien memiliki arah negatif menunjukkan bahwa penghindaran pajak yang dilakukan perusahaan maka biaya hutang perusahaan semakin turun.

Hasil penelitian ini berlawanan dengan penelitian yang dilakukan oleh Widya Sartika (2012) yang menyebutkan bahwa penghindaran pajak berpengaruh negative signifikan terhadap biaya hutang. Selain itu, penelitian ini juga berlawanan dengan hasil penelitian yang dilakukan oleh Dwi Martani (2011) yang menyebutkan bahwa pengaruh penghindaran pajak terhadap biaya hutang adalah signifikan positif. Adapun hal ini dimungkinakan diakibatkan karena peraturan pajak di Indonesia kurang memberikan insentif pengurang pajak (tax sheltering) pada perusahaan manufaktur. Peraturan pajak justru lebih ketat dalam memberian kriteria beban yang dapat dikurangkan dibandingkan dengan akuntansi. Periode pengamatan dilakukan pada saat pemerintah mengeluarkan UU KUP, melakukan reformasi perpajakan dan peningkatan pemberantasan korupsi. Hal ini menyebabkan kreditur justru memandang penghindaran pajak sebagai risiko.

\section{Pengaruh Moderasi Tarif Pajak Terhadap Hubungan Penghindaran Pajak (Tax Avoidance) dan Biaya Hutang (Cost of Debt)}

Berdasarkan analisis yang dilakukan untuk menguji pengaruh moderasi tarif pajak terhadap hubungan penghindaran pajak dan biaya hutang menunjukkan bahwa dari hasil uji t diperoleh nilai t hitung sebesar 0,103 dan tingkat signifikansi sebesar 0,918 (>0,05). Hasil ini menunjukkan bahwa perubahan tarif pajak tidak mampu memoderasi hubungan penghindaran pajak dan biaya hutang, sehingga hipotesis kedua dalam penelitian ini ditolak. Hasil ini berlawanan dengan penelitian yang dilakukan oleh Indah Masri dan Dwi Martani (2011), yang menyebutkan bahwa perubahan tariff pajak mampu memperkuat hubungan negative antara penghindaran pajak terhadap biaya hutang. Adapun hal ini dimungkinakan diakibatkan karena pada tahun sebelum perubahan tarif pajak (saat tarif pajak tinggi), pengaruh negatif penghindaran pajak terhadap biaya hutang semakin besar (semakin negatif) dibandingkan dengan pada periode setelah perubahan tarif pajak (tarif semakin rendah). Penjelasan yang menyebabkan terjadinya hal ini adalah pada saat tarif pajak tinggi perusahaan cenderung melakukan manajemen laba dengan menggeser penghasilan kearah tarif yang lebih rendah. Sehingga manajemen laba akan lebih rentan dilakukan pada periode sebelum penurunan

Jurnal Akuntansi Indonesia 
tarif pajak. Pada saat tarif pajak tinggi terdapat insentif yang kuat untuk melakukan pengelolaan laba pajak yaitu manajemen laba yang ditujukan untuk pajak. Sehingga dalam hal ini kreditur menganggap perilaku penghindaran pajak pada periode sebelum penurunan tarif pajak adalah hal yang wajar dan bagian dari tax planning.

\section{KESIMPULAN}

Berdasarkan hasil analisis data dan pembahasan yang telah diuraikan, dapat diketahui bahwa dari variabel bebas dan variabel kontrol serta variabel moderasi yang digunakan maka dapat ditarik kesimpulan; Variabel penghindaran pajak tidak berpengaruh signifikan terhadap biaya hutang. Variabel perubahan tarif pajak mampu memoderasi hubungan penghindaran pajak dan biaya hutang.

Untuk pengujian variabel kontrol, diketahui bahwa hanya variabel leverage dan cashflow operating (CFO) yang mempengaruhi biaya hutang, sedangkan umur, ukuran perusahaan, kualitas auditor dan PPE tidak mempengaruhi terjadinya biaya hutang.

\section{Keterbatasan Dan Saran}

Penelitian ini memiliki beberapa keterbatasan yang mungkin dapat menimbulkan gangguan terhadap hasil penelitian, diantaranya adalah :

1. Dalam penelitian ini hanya mengambil sampel dari perusahaan manufaktur yang terdaftar dalam $\mathrm{BEI}$, sehingga hasil penelitian akan berbeda atau tidak bisa digeneralisasi jika menggunakan seluruh perusahaan yang terdaftar dalam BEl.

2. Dalam penelitian ini diperoleh nilai Adjusted R square sebesar 10,1\%, hasil ini menunjukkan pengaruh yang diberikan penghindaran pajak, biaya hutang, perubahan tarif pajak, umur, ukuran perusahaan, leverage, kualitas auditor, CFO dan PPE terhadap biaya hutang relatif. Sehingga masih ada variabel lain yang memiliki pengaruh yang besar terhadap biaya hutang.

Memperhatikan adanya beberapa keterbatasan seperti yang telah disampaikan maka bagi penelitian selanjutnya perlu memperhatikan beberapa saran untuk penelitian selanjutnya berikut ini:

1. Pada penelitian selanjutnya diharapkan menggunakan sampel dari seluruh perusahaan dan menggunakan tahun pengamatan yang lebih panjang sehingga hasil penelitian dapat mengeralisasikan kondisi pasar modal pada seluruh perusahaan.

2. Pada penelitian selanjutnya disarankan untuk menambahkan variabel lain untuk mempengaruhi biaya hutang, yaitu kepemilikan manajerial, institusional, pertumbuhan penjualan dan lain sebagainya. 


\section{DAFTAR PUSTAKA}

Barr, N.A., James, S.R., \& Prest, A.R. (1977).Self-Assessment for Income Tax.London, Heinemann.

Christine. Basic Concept Of Tax Management. Jakarta.

DeAngelo, H.,\& Masulis, R.W. (1980). Optimal capital structure under corporate and personal taxation.Journal of Financial Economics 8, 3-29.

Dechow, P., Sloan, R., \& Sweeney, A., (1995). Detecting earnings management.The Accounting Review 70, $193-225$.

Desai, M.A. \& Dharmapala, D. (2006).Corporate tax avoidance and high-powered incentives.Journal of Financial Economics, 79, 145-179.

Graham, Tucker. (2006). Tax shelters and corporate debt policy. Journal of Financial Economics 81, 563-594. (2006).

Gujarati, Damodar. (2009). Basic Econometrics 5th Edition. New York : McGraw-Hill Book Co.

KMK No.1002/KMK.04/1984

Lim, Youngdeok. (2010). Tax avoidance, Cost of Debt and Shareholder Activism: Evidence from Korea. Journal of Banking \& Finance, 35 (2011) 456-470.

Sartika, Widya. (2012 ). Analisis Hubungan Penghindaran Pajak Terhadap Biaya Hutang dan Kepemilikan Institusional Sebagai Variabel Pemoderasi.Jakarta : Universitas Indonesia.

UU No.36 tahun 2008.Tentang perubahan keempat atas Undang-Undang No.7 tahun 1983 tentang Pajak Penghasilan. 
LAMPIRAN

Gambar 1

Model Penelitian

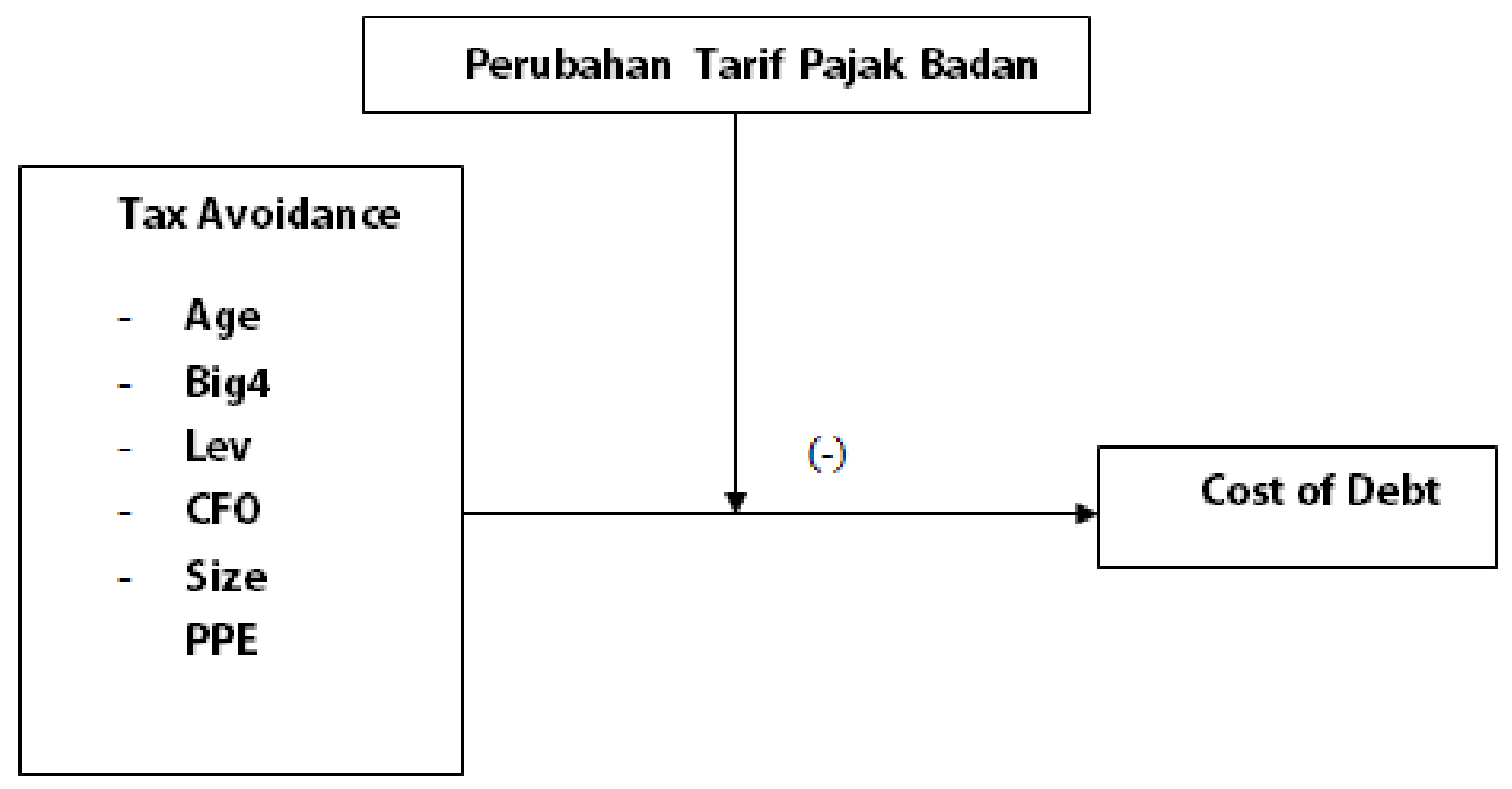

Gambar 2

Pengujian Normalitas Probability Plot

Normal P-P Plot of Regression Standardized
Residual

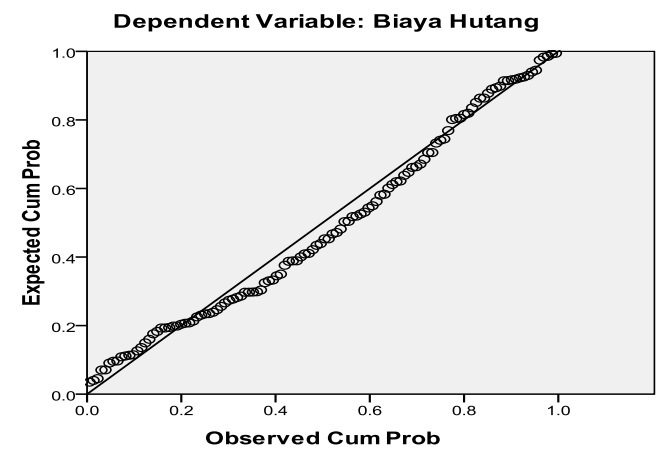




\section{Gambar 3}

Hasil Uji Heterkedastisitas

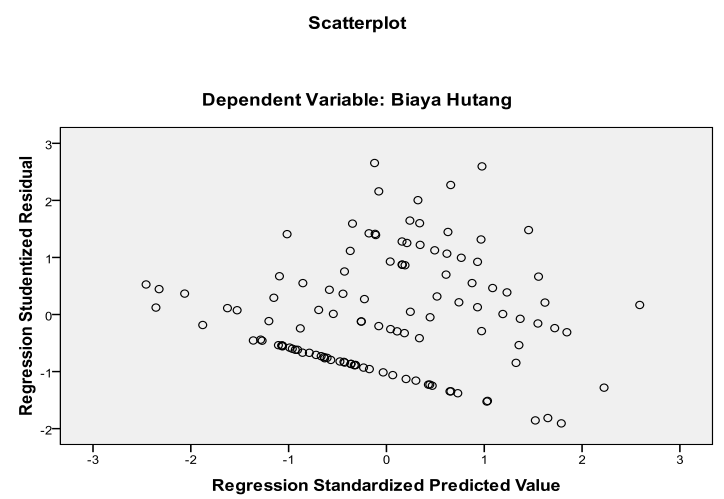

\section{Gambar 4}

\section{Hasil Uji Heterkedastisitas}

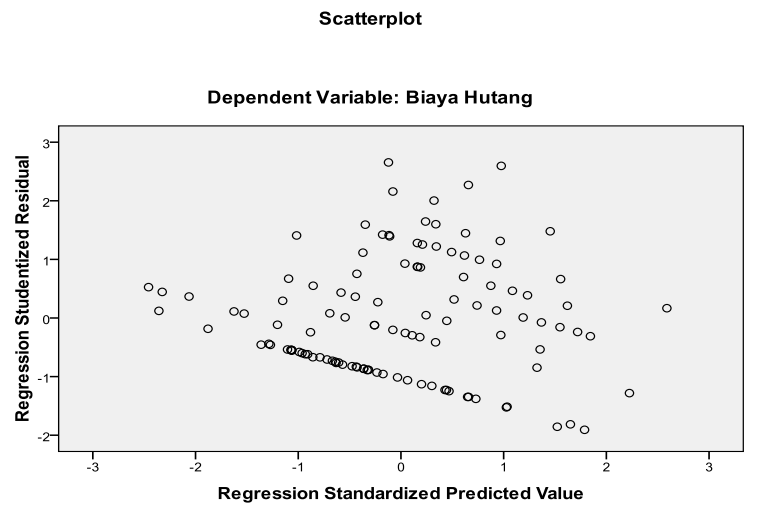

Tabel 1

Metode Pengambilan Sampel Penelitian

\begin{tabular}{lc}
\hline \multicolumn{1}{c}{ Keterangan } & Jumlah \\
\hline Perusahaan manufaktur yang terdaftar di BEI & 140 \\
\hline $\begin{array}{l}\text { Perusahaan yang laporan keuangannya tidak diukur menggunakan satuan } \\
\text { rupiah }\end{array}$ & 10 \\
\hline Perusahaan dengan data tidak lengkap & 57 \\
\hline Perusahaan yang memiliki pendapatan negatif & 33 \\
\hline Perusahaan sampel (yang memiliki laba diatas Rp 110.000.000) & 40 \\
\hline
\end{tabular}

Sumber : ICMD Tahun 2011 
Tabel 2

Deksriptif Statistik

\begin{tabular}{cccccc}
\hline & $\mathrm{N}$ & Minimum & Maximum & Mean & Std. Deviation \\
\hline TA & 120 & -15.89 & 1.97 & -.9345 & 1.55648 \\
\hline Cost & 120 & .00 & 1.07 & .0364 & .10067 \\
\hline Perubahan & 120 & .00 & 2.00 & 1.0000 & .81992 \\
\hline Umur & 120 & 2.00 & 33.00 & 17.4250 & 5.89497 \\
\hline Ukuran & 120 & 11.30 & 29.58 & 23.4247 & 5.07023 \\
\hline Leverage & 120 & .00 & 1.08 & .4024 & .20122 \\
\hline Kualitas & 120 & .00 & 1.00 & .5333 & .50098 \\
\hline CFO & 120 & .00 & 1.74 & .1478 & .18184 \\
\hline PPE & 120 & 7.97 & 28.60 & 21.4003 & 5.19951 \\
\hline Valid N (listwise) & 120 & & & &
\end{tabular}

Tabel 3

Uji Statistik Normalitas Residual Kolmogorov Smirnov

\begin{tabular}{ccc}
\hline & $\mathrm{N}$ & $\begin{array}{c}\text { Unstandardized } \\
\text { Residual }\end{array}$ \\
\hline \multirow{2}{*}{ Normal Parameters ${ }^{\mathrm{a}, \mathrm{b}}$} & & 120 \\
\cline { 2 - 3 } & Mean & .0000000 \\
\hline \multirow{2}{*}{ Most Extreme Differences } & Std. Deviation & .08922226 \\
\cline { 2 - 3 } & Absolute & .219 \\
\cline { 2 - 3 } & Positive & .219 \\
\hline Kolmogorov-Smirnov Z &. .149 \\
\hline \multicolumn{2}{c}{ Asymp. Sig. (2-tailed) } & 2.394 \\
\hline
\end{tabular}

a. Test distribution is Normal.

b. Calculated from data. 
Tabel 4

Pengujian Normalitas dengan Uji Statistik

Kolmogorov Smirnov Setelah Outlier

\begin{tabular}{|c|c|c|}
\hline & & $\begin{array}{c}\text { Unstandardized } \\
\text { Residual }\end{array}$ \\
\hline \multicolumn{2}{|c|}{$\mathrm{N}$} & 118 \\
\hline \multirow{2}{*}{ Normal Parameters ${ }^{\mathrm{a}, \mathrm{b}}$} & Mean & .0000000 \\
\hline & Std. Deviation & .02476550 \\
\hline \multirow{3}{*}{ Most Extreme Differences } & Absolute & .076 \\
\hline & Positive & .076 \\
\hline & Negative & -.043 \\
\hline \multicolumn{2}{|c|}{ Kolmogorov-Smirnov Z } & .829 \\
\hline \multicolumn{2}{|c|}{ Asymp. Sig. (2-tailed) } & .497 \\
\hline
\end{tabular}

a. Test distribution is Normal.

b. Calculated from data.

Tabel 5

Hasil Uji Multikolonieritas

\begin{tabular}{|c|c|c|c|c|c|}
\hline & \multirow{2}{*}{ Model } & \multicolumn{2}{|c|}{ Unstandardized Coefficients } & \multicolumn{2}{|c|}{ Collinearity Statistics } \\
\hline & & $B$ & Std. Error & Tolerance & VIF \\
\hline \multirow{10}{*}{1} & (Constant) & -.019 & .018 & & \\
\hline & TA & -.002 & .003 & .341 & 2.929 \\
\hline & Perubahan & .002 & .008 & .132 & 7.555 \\
\hline & Umur & .000 & .000 & .873 & 1.146 \\
\hline & Ukuran & -.002 & .001 & .202 & 4.955 \\
\hline & Leverage & .043 & .013 & .827 & 1.210 \\
\hline & Kualitas & -.002 & .005 & .866 & 1.154 \\
\hline & CFO & -.056 & .023 & .330 & 3.031 \\
\hline & PPE & .002 & .001 & .203 & 4.932 \\
\hline & Moderat & .000 & .005 & .123 & 8.119 \\
\hline
\end{tabular}




\section{Tabel 6}

Hasil Uji Autokorelasi Durbin-Watson

\begin{tabular}{|c|c|c|c|c|c|}
\hline Model & $\mathrm{R}$ & R Square & $\begin{array}{l}\text { Adjusted R } \\
\text { Square }\end{array}$ & $\begin{array}{l}\text { Std. Error of the } \\
\text { Estimate }\end{array}$ & Durbin-Watson \\
\hline 1 & $.423^{a}$ & .179 & .111 & .02578 & 1.777 \\
\hline \multicolumn{6}{|c|}{$\begin{array}{l}\text { a. Predictors: (Constant), Moderat, Ukuran, TA, Umur, Kualitas, Leverage, CFO, PPE, } \\
\text { Perubahan }\end{array}$} \\
\hline
\end{tabular}

Tabel 7

Hasil Uji Autokorelasi Dengan Run Test

\begin{tabular}{cc}
\hline & $\begin{array}{c}\text { Unstandardized } \\
\text { Residual }\end{array}$ \\
\hline Test Value $^{\mathrm{a}}$ & -.00349 \\
\hline Cases $<$ Test Value & 59 \\
\hline Cases $>=$ Test Value & 59 \\
\hline Total Cases & 118 \\
\hline Number of Runs & 54 \\
\hline Z & -1.109 \\
\hline Asymp. Sig. (2-tailed) & .267 \\
\hline
\end{tabular}

Tabel 8

Hasil Uji Koefisien Determinasi

\begin{tabular}{ccccc}
\hline Model & $\mathrm{R}$ & R Square & $\begin{array}{c}\text { Adjusted } \mathrm{R} \\
\text { Square }\end{array}$ & $\begin{array}{c}\text { Std. Error of the } \\
\text { Estimate }\end{array}$ \\
\hline 1 & $.423^{\mathrm{a}}$ & .179 & .111 & .02578 \\
\hline
\end{tabular}

a. Predictors: (Constant), Moderat, Ukuran, TA, Umur, Kualitas, Leverage, CFO, PPE, Perubahan

b. Dependent Variable: Biaya Hutang 
Tabel 9

Hasil Uji Simultan (Uji F)

\begin{tabular}{|c|c|c|c|c|c|c|}
\hline & Model & $\begin{array}{l}\text { Sum of } \\
\text { Squares }\end{array}$ & $d f$ & Mean Square & $\mathrm{F}$ & Sig. \\
\hline \multirow{3}{*}{1} & Regression & .016 & 9 & .002 & 2.620 & $.009^{\mathrm{a}}$ \\
\hline & Residual & .072 & 108 & .001 & & \\
\hline & Total & .087 & 117 & & & \\
\hline
\end{tabular}

a. Predictors: (Constant), Moderat, Ukuran, TA, Umur, Kualitas, Leverage, CFO, PPE, Perubahan

b. Dependent Variable: Biaya Hutang

Tabel 10

Hasil Analisis Koefisien Regresi dan Uji t

\begin{tabular}{|c|c|c|c|c|c|c|}
\hline & \multirow[t]{2}{*}{ Model } & \multicolumn{2}{|c|}{ Unstandardized Coefficients } & \multirow{2}{*}{$\begin{array}{c}\begin{array}{c}\text { Standardized } \\
\text { Coefficients }\end{array} \\
\text { Beta } \\
\end{array}$} & \multirow[t]{2}{*}{$\mathrm{T}$} & \multirow[t]{2}{*}{ Sig. } \\
\hline & & $\mathrm{B}$ & Std. Error & & & \\
\hline \multirow{10}{*}{1} & (Constant) & -.019 & .018 & & -1.023 & .309 \\
\hline & $\mathrm{TA}$ & -.002 & .003 & -.110 & -.738 & .462 \\
\hline & Perubahan & .002 & .008 & .057 & .239 & .812 \\
\hline & Umur & .000 & .000 & -.051 & -.546 & .586 \\
\hline & Ukuran & -.002 & .001 & -.309 & -1.594 & .114 \\
\hline & Leverage & .043 & .013 & .304 & 3.175 & .002 \\
\hline & Kualitas & -.002 & .005 & -.042 & -.447 & .656 \\
\hline & CFO & -.056 & .023 & -.377 & -2.486 & .014 \\
\hline & PPE & .002 & .001 & .360 & 1.859 & .066 \\
\hline & Moderat & .000 & .005 & .026 & .103 & .918 \\
\hline
\end{tabular}

a. Dependent Variable: Biaya Hutang 